\title{
Geochemical controls on the partitioning and hydrological transport of metals in a non-acidic river system
}

\author{
J. Thorslund ${ }^{1}$, J. Jarsjö ${ }^{1}$, T. Wällstedt ${ }^{2}$, C. M. Mörth ${ }^{3}$, M. Y. Lychagin ${ }^{4}$, and \\ S. R. Chalov ${ }^{4}$ \\ ${ }^{1}$ Department of Physical Geography and Quaternary Geology and the Bolin Centre for Climate \\ Research, Stockholm University, Svante Arrhenius väg 8 C, 10691 Stockholm, Sweden \\ ${ }^{2}$ Department of Applied Environmental Science, Stockholm University, \\ Svante Arrhenius väg 8 C, Stockholm University, 10691 Stockholm, Sweden \\ ${ }^{3}$ Department of Geological Sciences, Stockholm University, Svante Arrhenius väg 8, \\ 10691 Stockholm, Sweden \\ ${ }^{4}$ Lomonosov Moscow State University, Faculty of Geography, 119991 Leninskie gory, 1, \\ Moscow, Russia
}

Received: 26 May 2014 - Accepted: 23 July 2014 - Published: 18 August 2014

Correspondence to: J. Thorslund (josefin.thorslund@natgeo.su.se)

Published by Copernicus Publications on behalf of the European Geosciences Union.

9715

\section{Abstract}

The speciation of metals, i.e. in which chemical form they occur, controls their mobility, bioavailability and toxicity. The overall objective of this study is to extend the knowledge on the spreading of metals in non-acidic river systems; this knowledge is currently

5 much more limited than the knowledge on metal behavior under acidic conditions that for instance are found in acid mine drainage systems. We combine novel measurements of metal spreading under distinctly high-pH conditions (up to 9.6) in the Tuul River at the Zaamar Goldfield mining site (Upper Lake Baikal Drainage Basin, Mongolia) with a geochemical modelling approach (Visual MINTEQ). Total mass flows of 10 several metals ( $\mathrm{Al}, \mathrm{Cd}, \mathrm{Fe}, \mathrm{Mn}, \mathrm{Pb}$ and $\mathrm{V}$ ) showed net increases over the mining site, with metals in suspension generally dominating the total export from the site. Model results showed that a main difference from acid mine drainage geochemistry is that the prevailing high $\mathrm{pH}$ causes precipitation of ferrihydrite and gibbsite, which removed between 90 to $100 \%$ of $\mathrm{Fe}$ and $\mathrm{Al}$ from solution. This notably influenced the behav-

15 ior of $\mathrm{As}, \mathrm{Pb}$ and $\mathrm{V}$ since their solubilities are controlled by sorption onto ferrihydrite. The combined effects from such geochemical processes (precipitation, sorption) hence explain the high impact of suspended transport to total transport under high $\mathrm{pH}$ conditions. Arsenic furthermore showed dissolved concentrations above health risk-based guideline values in several locations and can thus be of main toxic concern in the upper Lake Baikal Drainage Basin. Moreover, present modelling showed that in particular the solubility of $\mathrm{Fe}, \mathrm{Pb}$ and $\mathrm{Zn}$ can increase considerably as DOC concentrations increase due to metal-organic complexation. In high pH systems, seasonality of DOC concentrations can therefore have a major influence on the spreading and toxicity of these metals, as can DOC trends caused by land use change. Present results also suggest 25 that the behavior of $\mathrm{Cr}$, $\mathrm{Cu}$ and Mo would be much better understood if a dependable adsorption database for hydroxyapatite could be developed. 


\section{Introduction}

Metals can become exposed to the environment through natural processes, such as weathering of soil and bedrock, and through anthropogenic processes, such as mining, industry and agriculture. They can enter aqueous systems through wash out from

5 surface soils, diffuse groundwater inflow, metal mobilization from enriched sediments, leaching from agricultural areas and mine tailings, catastrophic tailings dam failure and discharge of industrial and mining effluents (e.g. Hudson-Edwards, 2003; Macklin et al., 2006; Mighanetara et al., 2009; Inam et al., 2011). Material mobilization via bank and bed erosion under conditions of geomorphic adjustment can dominate pollutant trans-

10 port under certain conditions (Lewin and Macklin, 1986; Chalov et al., 2014). Once metals are released into aquatic systems they persist in the environment, since they are non-degradable. Metals held in alluvial stores may therefore continue to pose a threat to ecosystems, long after their initial release, and alluvial sediments may possibly constitute the most significant source of catchment heavy metal pollution (Dennis, 2005;

15 Alexeevsky et al., 2013).

Mounting evidence over the last decades have shown that the speciation of metals (i.e. in which chemical form they occur) controls their mobility, bioavailability and toxicity (e.g. Tessier and Campbell, 1979; Tack and Verloo, 1995; Tipping, 1998; Fytianos, 2001; Landner, 2005). The dissolved form, especially the dissolved inorganic fraction,

20 is considered to be the most toxic form of the majority of metals (e.g. Gundersen and Steinnes, 2001; Nystrand et al., 2012), since it can readily be taken up by organisms and biota (e.g. Törnqvist et al., 2011; Raguz et al., 2013). Many chemical factors and parameters need to be accounted for in determining the speciation, such as $\mathrm{pH}$, redox conditions, oxidation state of the metal and available surfaces for adsorption (e.g.

25 Palleiro et al., 2013). An advantage of equilibrium speciation models is the possibility to predict dominating forms and evaluate controlling mechanisms, such as sorption and precipitation reactions (Lund et al., 2008). Frequently used speciation models include WHAM (Tipping, 1994), PHREEQC (Parkhurst and Appelo, 1999) and Visual

9717

MINTEQ (Gustafsson, 2009), which are used for both groundwater and surface water applications (e.g. Tipping and Lawlor et al., 1998; Butler et al., 2004; Gustafsson et al., 2009; Korfali and Davies, 2004; Wällstedt et al., 2010; Nystrand et al., 2012). They have the ability to represent surface complexation reactions and binding to organic 5 matter, which are all central to metal transport and partitioning between the water and sediment phase (e.g. Butler et al., 2008).

Although there are many studies on speciation modeling of metals in aqueous systems (e.g. Eary, 1999; Butler et al., 2004; Balistrieri et al., 2007; Gustafsson et al., 2009; Nystrand et al., 2012), the majority of them have focused on metal behavior - under acidic or near neutral conditions rather than metal behavior under high $\mathrm{pH}$ conditions. Some exceptions are for example a study by Sjöstedt et al. (2009) who measured and modeled the speciation of $\mathrm{Al}$, As and Mo in Swedish lakes that had been limed to near neutral $\mathrm{pH}$ and a study by Moldovan and Hendry (2005) who modeled the speciation of As, leaching from uranium mining, up to $\mathrm{pH} 11$. In addition to speciation

15 modeling studies, others have highlighted pollution problems of metals in non-acidic systems (see e.g. Tarras-Wahlberg et al., 2000; Sjöblom et al., 2004; Grosbois et al., 2009; Zak et al., 2009), often showing high metal concentrations in particles but low concentrations in the dissolved form, hence indicating that geochemical controls and dominating processes might differ from well-studied acidic pollution sources.

Furthermore, understanding geochemical controls in combination with physical transport of metals could greatly enhance metal transport and fate predictions (Foster and Charlesworth, 1996; Destouni et al., 2010; Persson et al., 2011). For example, geochemical processes (e.g. adsorption) influence whether or not certain physical processes (e.g. suspended sediment transport; Chalov et al., 2012) will be important for

25 the overall transport of metals. There are however relatively few studies that address these combined effects of physical and chemical controls on metals in aqueous systems (e.g. Caruso et al., 2008; Malmström et al., 2008).

The overall objective of this study is to extend the knowledge on the spreading of metals in non-acidic river systems. We combine novel site specific measurements with 
a geochemical modelling approach (Visual MINTEQ), specifically aiming at (i) evaluating the performance of using this modeling approach by comparing observations and model predictions, (ii) identifying dominating solids and predict the capacity of these solids to sorb and/or co-precipitate other metals that are transported in suspension 5 and (iii) identify dominant controls keeping metals in solution, such as soluble complexation.

As an application example, we consider the distinctly high-pH conditions (Pietron, 2012; Thorslund et al., 2012; Chalov et al., 2012, 2014) of the Tuul River, at Zaamar Goldfied, in Mongolia. It is the largest gold mining site within the Tuul River basin, com-

10 prising a widespread source zone. The Tuul River connects to the Orkhon-Selenga River system and is a highly polluted river in the upstream Mongolian part of the transboundary Russian-Mongolian Lake Baikal drainage basin. The many mining companies within Zaamar Goldfield, as well as illegal mining, is considered to have serious impact on the water quality within the river basin (Altansukh and Davaa, 2011; Chalov

15 et al., 2012; Thorslund et al., 2012) and could possibly have an impact on downstream Selenga river and Lake Baikal. Although total (suspended and dissolved) concentrations and mass flows of several metals within this system were high, dissolved concentrations were generally low. In the downstream regions of the Lake Baikal drainage basin however, increasing metal pollution of both sediments and biota has been re-

20 ported (e.g. Rudneva et al., 2005; Khazheeva et al., 2006). Investigating controls on metal partitioning between the sediment and water phase is thus of particular importance for this system, since metals originating from Zaamar Goldfield could potentially be transported all the way to the vicinity of Lake Baikal that hosts a unique ecosystem and comprises a huge water resource.

\section{Site description}

The mining areas of Zaamar Goldfield are located along the Tuul River valley, between Latitude: $48^{\circ} 17^{\prime} 50^{\prime \prime} \mathrm{N}$ and Longitude: $104^{\circ} 24^{\prime} 65^{\prime \prime} \mathrm{E}$ (Fig. 1) (AATA, 2008),

$$
9719
$$

approximately $600 \mathrm{~km}$ upstream of the Lake Baikal inlet (AATA, 2008). The Tuul River is a tributary to the Selenga River, a transboundary river between Mongolia and Russia, which is by far the largest river draining into Lake Baikal (Lee et al., 2006), discharging about $30 \mathrm{~km}^{3}$ of water and 3.5 million tons of sediments annually into the lake area.

5 Before the Selenga River flows into Lake Baikal there is the Selenga delta, covering an area of about $1200 \mathrm{~km}^{2}$ (USGS, 2011).

Annual average discharge of the Tuul River is $27 \mathrm{~m}^{3} \mathrm{~s}^{-1}$ (1945-2007), but maximum discharges in the summer period can reach values of around $80 \mathrm{~m}^{3} \mathrm{~s}^{-1}$, whereas decreasing discharges are marked throughout the coldest months of the year (November-

10 March). After the junction of the Tuul River with the Orkhon River, discharges on average increase by an order of magnitude and in the downstream Selenga River, annual average discharge reaches just over $1000 \mathrm{~m}^{3} \mathrm{~s}^{-1}$ (GEMStat, 2011; MCA, 2011). The average yearly precipitation in the region is between 200 and $250 \mathrm{~mm}$. The climate of the region is semi-arid with warm and dry summers (averaging temperatures of $1520^{\circ} \mathrm{C}$ ), although intense rainfalls do occur, and cold winters (averaging temperatures of $-20^{\circ} \mathrm{C}$ ) (AATA, 2008).

The geology of the area includes sedimentary, igneous, and metamorphic rock formations, such as sedimentary sand and siltstones, igneous gabbros, and metamorphic schists. The region is also naturally consisting of calcium bicarbonates to a large de20 gree (Altansukh and Davaa, 2011) and there are strong interactions between surface waters and groundwater, due to extensive areas of alluvial unconfined aquifers in the river valleys (Zandaryaa et al., 2008). This impacts the Tuul River quality and quantity, which is fed by groundwater inflows with high water-rock interactions; affecting the $\mathrm{pH}$ values throughout Zaamar Goldfield to be high (Lee et al., 2006; Zandaryaa et al., 25 2008).

Zaamar Goldfield is the largest gold mining site within the Tuul basin and the extensive source zone contains both alluvial and hard rock mining that stretches for about $45 \mathrm{~km}$ along the floodplain of the Tuul River (Lee et al., 2006). The many mining activities over widespread areas and the lack of control of tailing and leakage from settling 
ponds contribute to both diffuse and direct pollution of soil, groundwater and surface water (Zandaryaa et al., 2008). High levels of metals have been measured in the Tuul River (Lee et al., 2006; AATA, 2008) and previous mass balance quantifications have shown a net increase in metal loading over the mining zone, especially of metals in 5 suspension (Thorslund et al., 2012).

\section{Methods of data collection and analysis}

\subsection{Field methods and sample collection}

Water samples were collected from the Tuul River at five locations around Zaamar Goldfield during two field campaigns; one in June 2012 and one in September 2013.

10 Information about the sampling locations, including coordinates, are shown in Table 1 and Fig. 1. Relatively low water discharges were observed during June 2012 campaign $\left(Q=13-15 \mathrm{~m}^{3} \mathrm{~s}^{-1}\right)$, whereas significant flooding with floodplain inundation was documented during September 2013 field campaign $\left(Q=45-52 \mathrm{~m}^{3} \mathrm{~s}^{-1}\right)$. The hydrometerological conditions also varied between the seasons, e.g. relatively dry weather 15 during the 2013 campaign and abundant rainfalls in the 2012 campaign.

The sampling procedure included grab sampling of water in plastic polypropylene bottles $(500 \mathrm{~mL})$, directly from the river, just below the surface. All sampling bottles were rinsed with the selected water before collecting the sample for analysis. The bottled water was then transferred into two high-density polypropylene test tubes $(10 \mathrm{~mL})$; one 20 unfiltered sample and one filtered sample (filtered through a $0.20 \mu \mathrm{m}$ pore membrane filter). In the 2013 campaign, three replicates for both filtered and unfiltered samples were collected. All test tubes were rinsed thoroughly with the sampled water before collecting the sample for analysis. The samples were acidified (1\%) with concentrated $\mathrm{HNO}_{3}(65 \%)$ to conserve them for analysis and prevent precipitation of metals.

Temperature and $\mathrm{pH}$ were measured in situ, directly in the river, using a Hannah Instrument HI 9828 meter (2012) and HI 98108 (2013). The meters were calibrated with

9721

$\mathrm{pH} 7$ and 10 solutions before each measurement campaign and then recalibrated during the campaigns. In the 2012 campaign, alkalinity was measured at Moscow State University using the standard titration method, while in the 2013 campaign it was measured using a Total Alkalinity test kit (HI 38014) directly in field.

Additionally in the 2013 campaign, an extended sampling procedure including samples for total and dissolved organic carbon (TOC/DOC) were collected into $30 \mathrm{~mL}$ highdensity polypropylene test tubes (three replicates). The DOC samples were filtered with $0.22 \mu \mathrm{m}$ pore membrane filters. All samples were then acidified $(1 \%)$ with concentrated acid $\mathrm{HNO}_{3}(65 \%)$ and wrapped in aluminum foil to prevent light from penetrating

10 it. These procedures were all made directly in the field. Samples for anion $\left(\mathrm{F}^{-}, \mathrm{Cl}^{-}\right.$, $\mathrm{NO}_{3}^{-}, \mathrm{SO}_{4}^{-2}, \mathrm{Br}^{-}$) analysis were also sampled in 2013 and collected into high-density polypropylene test tubes of $10 \mathrm{~mL}$ (three replicates) without further preservation.

\subsection{Analytical methods}

All samples discussed in the present paper were analysed at Stockholm University.

15 Metal concentrations were analysed with inductive coupled plasma optical emission spectrometry (ICP-OES) with the Thermo iCAP 6500 Duo analyser, to determine the contents of; Al, As, B, Ba, Ca, Cd, Co, Cr, Cu, Fe, K, Mg, Mn, Mo, Na, Ni, P, Pb, S, $\mathrm{Si}, \mathrm{Sn}, \mathrm{Sr}, \mathrm{Ti}, \mathrm{V}$ and $\mathrm{Zn}$. The analysis of samples followed standard procedures using a micro concentric nebulizer and in some cases an ultra sonic nebulizer, CETAC USN

20 U5000AT + in order to get better detection limits. Eleven metals were selected from the analytical result dataset for further interpretation and modeling purposes; Al, As, $\mathrm{Cd}, \mathrm{Cr}, \mathrm{Cu}, \mathrm{Fe}, \mathrm{Mn}, \mathrm{Mo}, \mathrm{Pb}, \mathrm{V}$ and $\mathrm{Zn}$. They were selected because these metals are often found at mining sites (e.g. Hudson-Edwards, 2003) and because of their potential toxicity to humans and biota. Mercury $(\mathrm{Hg})$ is a metal that is often associated with

25 mining activities but was here excluded since it requires different analytical procedures from those performed here, i.e. fluorescence method. Furthermore, previously reported measurements show repeatedly that concentrations have been low and in many cases below detection limits in recent (2006-2011) years (Thorslund et al., 2012). Total and 
dissolved organic carbon (TOC/DOC) were analysed using an NPOC (non-purgeable organic carbon) measurement using the analyzer Shimadzu TOC-L CPH. Major anion analysis were performed by liquid chromatography using the IC20 Dionex, following Swedish standard procedures (EN-ISO 10304-1:2009).

\section{3.3 Discharge measurements and mass flow estimates}

Discharge was measured at the sampling locations along the Tuul River, at the same place and time as water samples were collected for chemical analysis. Measurements were made by wading, by boat or from bridges (depending on the depth of each river section). Velocities were measures with a hydrometric propeller (ISP-1) at 0.6 depth

10 (from the surface) of each width increment. When the depth exceeded $1.5 \mathrm{~m}$ an Acoustic Doppler Profiler (ADP) was used, which measures water level and velocity at horizontal profiles across a channel. The discharge of each cross-section was calculated according to Eqs. (1) and (2)

$Q=\sum_{1}^{n} V_{n} \cdot A_{n} \cdot k$

15 where $V_{n}$ is the velocity of each width increment, $A_{n}$ is the area of each rectangular subsection, using the Trapezoidal rule;

$A_{n}=\frac{d_{n}+d_{n-1}}{2} \cdot\left(b_{n}-b_{n-1}\right)$.

The coefficient $k$ in Eq. (1) is used when the expression is applied to non-steep banks; here $k$ is equal to 0.7 (Bykov and Vasil'ev, 1972). In Eq. (2) $d$ is the depth of each 20 subsection and $b$ is the distance from the bank.

The discharges, $Q$, were multiplied with concentrations, $C$, according to Eq. (3) to yield estimates of dissolved and total metal mass flows, Mf, over the five cross-sections along the Tuul River.

$\mathrm{Mf}=C \cdot Q$

9723

The simultaneous measurements of pollutant concentrations and discharges were made to get snapshot values of loads along the river reach and over Zaamar Goldfield.

\subsection{Modeling approach}

5 The geochemical equilibrium model Visual MINTEQ vers. 3.0 (Gustafsson, 2011) was used to model the speciation of selected metals. This model calculates the chemical composition of various inorganic ions in aqueous systems, in a single point (e.g. a water sample), under the assumption of a chemical equilibrium state.

Input variables were the following; total concentrations of all elements analysed (see

10 Table 2 for chosen oxidation states), major anion concentrations, $\mathrm{pH}$, alkalinity $\left(\mathrm{HCO}_{3}^{-}\right)$, temperature, pe (redox potential) and DOC (dissolved organic carbon) for each sampling point. Studies (e.g. Nystrand et al., 2012) have shown that modeling results are more accurate if they are based on concentrations of a relatively high number of elements in the input data, since this gives a better representation of the chemistry in the

15 water sample (ionic strength and complex binding is then better represented) and thus decrease uncertainties in model calculations. Concentration data of all elements determined in the ICP-OES analysis were therefore used as input variables (see Sect. 3.2). However, in the subsequent sections, the model outputs for the eleven selected metals are presented and furthered discussed.

20 To test the impact of $\mathrm{pH}$ on the speciation, model runs for each sample were made for two different acidic pH conditions; $\mathrm{pH} 3.5$ and pH 6.

DOC and major anions were not measured during the field campaign in 2012. Thus, for the modeling of the 2012 data, DOC values from the 2013 campaign were used. In addition to this, a $50 \%$ increased DOC value was modeled for the 2012 data, to 25 investigate the sensitivity to changing $\mathrm{DOC}$ concentrations. Since Sulfate $\left(\mathrm{SO}_{4}^{2-}\right)$ and Chloride $\left(\mathrm{Cl}^{-}\right)$concentrations were not measured in the 2012 campaign they had to be approximated. Sulfate concentrations were assumed to equal half of measured Sulfur 
(S) concentrations and Chloride concentrations were set to equal measured Sodium (Na) concentrations.

The redox potential (pe) was estimated according to Eq. (4) for both years, which is assumed representative for well oxygenated waters (Stumm and Morgan, 1996).

$5 \mathrm{pe}=20.77+\frac{1}{4} \log p \mathrm{O}_{2}-\mathrm{pH}$

where $p \mathrm{O}_{2}$ was assumed to equal $0.2 \mathrm{~atm}$ (i.e. the $\mathrm{O}_{2}$ content in the atmosphere is $20.95 \%$ ), similar to what Wällstedt et al. (2010) used in their study.

The solids that were allowed to precipitate when their respectively solubility constant was exceeded are shown in Table 3. These were chosen based on (i) knowledge about 10 common solids for the present geological conditions at the study site, and (ii) model outputs of "saturation indices", indicating which minerals could precipitate, based on site specific data and thermo dynamical calculations.

Adsorption to ferrihydrite and gibbsite was estimated using the DLM (diffuse layer model) according to Dzombak and Morel (1990) and Karamalidis and Dzombak (2010)

15 respectively. The DLM is a surface complexation model that simulate the distribution of each metal ion between the dissolved form and adsorbed to a solid (Gustafsson et al., 2009). Both of these minerals were selected due to their high measured particulate concentrations and their sorption capacities. Published data on the solubility of gibbsite varies and is mainly a function of $\mathrm{pH}$, sulfate, fluoride and DOC concentra-

20 tions. The main difficulty lies in that it is hard in natural systems to separate amorphous $\mathrm{Al}(\mathrm{OH}) 3$ from gibbsite. Because of this difficulty the solubility of $\mathrm{Al}$ is restricted and its database in Visual MINTEQ is more limited than for ferrihydrite. ferrihydrite is an iron mineral which is a frequently used solid for adsorption in Visual MINTEQ and the adsorption database for this solid is thus extensive. Ferrihydrite is well known for its

25 metal retention capacity due to large surface sites for adsorption and has been shown to correlated well with measured data (e.g. Sjöstedt et al., 2010; Nystrand et al., 2012; Tiberg et al., 2013). Adsorption constants for Vanadium adsorption to ferrihydrite was

9725

change according to Wällstedt et al. (2010). All other parameter values in this menu were kept on default.

For simulation of complexation of the metals with dissolved organic matter the "Stockholm humic model" (SHM) was used. This model uses a discrete-site approach to rep5 resent the metal-humic complexation, similar to the model described by Tipping (1994). The default ratio of 1.65 between active DOM (i.e. the part of the organics that binds to the metals) and DOC (dissolved organic Carbon) was assumed representative and thus not changed. All of the DOM was assumed to be fulvic acid, based on earlier studies (e.g. Khai et al., 2008; Sjöstedt et al., 2010; Wällstedt et al., 2010; Gustafsson 10 et al., 2014), which is also set as default in the model.

\section{Results}

\subsection{Tuul River water chemistry}

Geochemical parameter values, used for the model input, representative for the five sampling locations along the Tuul River reach (T5-T6a) are shown in Table 4. The $\mathrm{pH}$

15 shows in all cases alkaline conditions, with values ranging between 9.6 (T5a) to 8.5 (T6) in the 2012 campaign and between 9.2 (T5a) to 7.6 (T5a) in the 2013 campaign. DOC concentrations vary between $10-12 \mathrm{mg} \mathrm{L}^{-1}$ throughout the measured river locations. TOC concentrations were on average only a few percent higher than DOC concentrations, hence dissolved organic matter is dominating the total organic matter composi-

20 tion. Estimated alkalinity values are very high, especially from field measurements in 2013. However, changing the alkalinity values in the model input did not change the speciation of selected metals, indicating low sensitivity for this parameter.

Dissolved and total riverine concentrations for the selected metals in the 2012 and 2013 campaigns are shown in Fig. 2a-k. In case of no detectable results, the midpoint

25 of the possible concentration range is shown in a lighter color for illustrative purposes (see Table A1 for DL values). The results show that concentration levels are generally 
in the same order of magnitude during both snapshot measurements (2012 and 2013), with the exception of total concentrations of $\mathrm{Al}, \mathrm{Cd}$ and $\mathrm{Mn}$ which are up to one order of magnitude greater in the 2012 campaign. The differences between particulate and dissolved concentrations are greatest for $\mathrm{Al}$, Fe and Mn with particulate concen5 trations being on average 178, 35 and 25 times greater than dissolved concentrations in the 2012 campaign respectively 42,18 and 5 times greater in the 2013 campaign. As, $\mathrm{Cd}, \mathrm{Cr}, \mathrm{Cu}$ and Mo, have dissolved concentrations within the same order of magnitude as their total concentrations. $\mathrm{V}$ and $\mathrm{Zn}$ show varying behaviour, both having higher dissolved and particulate concentrations depending on sampling point. Overall,

10 total concentrations show a net increase over the site, with increased values at the most downstream point (T6a) compared to the upstream points (T5, T5a), with the exception of $\mathrm{Zn}$ and Mo. Several metals (Al, As, Fe and Mn) show total (unfiltered) concentrations that exceeds $\mathrm{WHO}$ and Mongolian health risk-based guideline values (Table B1). As additionally shows dissolved (filtered) concentrations exceeding these 15 health risk-based guideline values.

\subsection{Riverine mass flows}

Dissolved and total (dissolved + suspended) mass flows at the five locations along the Tuul River from the campaigns in 2012 and 2013 are shown in Fig. 3a-k (note the different scales on the $y$-axis). The first location (T5) is not included in the 2013 campaign due to discharge data missing. Taken together, the majority of metals from both campaign years show net increasing total mass flows over Zaamar Goldfield, with values being higher at the most downstream point (T6a) than the most upstream (T5, T5a) points. Due to above mentioned high dissolved and total concentration differences, differences between dissolved and total mass flows are generally high, with total mass

25 flows being up to two orders of magnitude higher than dissolved mass flows, especially for $\mathrm{Al}, \mathrm{Fe}$ and $\mathrm{Mn}$. Similarly, dissolved mass flows of As, Cd, Cr, Cu and Mo are generally of the same magnitude as total mass flows. Total mass flows of most metals

9727

(As, $\mathrm{Cr}, \mathrm{Cu}, \mathrm{Fe}, \mathrm{Mo}, \mathrm{Pb}, \mathrm{V}$ and $\mathrm{Zn}$ ) were higher in the 2013 campaign than in the 2012 campaign (median: 5 times higher).

\subsection{Modeling results}

\subsubsection{Comparing observations and model predictions}

5 Figure 4 compares measurement and modeling results on the dissolved fraction (percentage) of considered metals and sampling locations in the (a) 2012 and (b) 2013 campaign. $\mathrm{Cr}, \mathrm{Cu}$ and Mo were always predicted to be $100 \%$ dissolved while $\mathrm{Mn}$ was predicted to be $100 \%$ precipitated throughout the study, although measured dissolved fractions were changing with location (see Tables $\mathrm{C} 1$ and $\mathrm{C} 2$ for values). This is fur-

10 ther discussed later (Sect. 5). For all other metals (Al, As, Cd, Fe, Pb, V and Zn; Fig. 4) model predictions in both campaign years agreed well with measurements (within $20 \%$ difference between measured and modeled results) for the majority of metals and locations (73\% of all data points in 2012 and $82 \%$ in 2013). Large discrepancies (i.e. $>20 \%$ difference) between measured and modeled results were more common in the

152012 campaign ( $27 \%$ of all data) than in the 2013 campaign ( $18 \%$ of all data). The overall best agreement was for $\mathrm{Al}$ and $\mathrm{Fe}(<5 \%$ average difference between measured and modeled results) whereas the least good agreement was for $\mathrm{Cd}$ ( $35 \%$ average difference).

\subsubsection{Speciation of metals}

20 Refined speciation modeling results for the Tuul River reach is shown in Fig. 5a-g (2012) and Fig. 6a-g (2013). Here the measured "dissolved" fraction of the total concentration is divided into two fractions; "dissolved inorganic" and "bound to DOM". These model results hence together make up was measured as "dissolved" (filtered samples). Furthermore, the modeled "sorbed" and "precipitated" fractions together cor25 respond to the measured "total" fraction (unfiltered samples). 
$\mathrm{Al}$ and Fe were predicted to dominantly occur as particulate gibbsite and ferrihydrite (90-100\%), respectively, throughout the river sections, for both campaign years. A small fraction of $\mathrm{Fe}$ (up to $5 \%$ ) was predicted to occur as soluable organic complex (bound to DOC). As, $\mathrm{Pb}$ and $\mathrm{V}$ were predicted to sorb to ferrihydrite, on average by $10 \%$ 5 (As) respectively $40 \%(\mathrm{~Pb}$ and $\mathrm{V})$, but with highest predicted sorption to ferrihydrite of $60 \%$. However, the dissolved inorganic forms of As (hydrogen arsenate; $\mathrm{HAsO}_{4}^{2-}$ ) and $\mathrm{V}$ (hydrogen vanadate; $\mathrm{HVO}_{4}^{2-}$ ) were predicted to dominate in both years. At location T6 (2012), Pb was predicted to sorb more to gibbsite than to ferrihydrite. This location had a very high measured particulate Al concentration (see Fig. 2). The concentration was

- twice as high as the concentration of $\mathrm{Fe}$, reaching over $6000 \mathrm{\mu g} \mathrm{L}^{-1}$. $\mathrm{Zn}$ was predicted to sorb only to gibbsite throughout all modelled locations, on average by adsorbing $50 \%$ (in 2013) to $80 \%$ (in 2012) to gibbsite. Cd was predicted to bound strongly to DOC in both years, on average by $75 \%$, although with some sorption to gibbsite (mainly in the 2012 campaign). $\mathrm{Pb}$ and $\mathrm{Zn}$ were also predicted to bind to DOC, on average by $55 \%$ 15 respectively $40 \%$ in the 2013 campaign and about $20 \%$ less in the 2012 campaign. Overall, comparing the speciation between the two field campaigns suggest that $\mathrm{Cd}$, $\mathrm{Pb}$ and $\mathrm{Zn}$ had higher average solubility during the latter occation in 2013 (i.e. more modeled as either dissolved inorganic and/or bound to DOM) with $15 \%(C d)$ and $20 \%$ $(\mathrm{Pb}$ and $\mathrm{Zn})$.

The modelling runs where $\mathrm{pH}$ was lowered to 6 respectively 3.5 generally increased the dissolved fraction of most metals. At $\mathrm{pH} 3.5,100 \%$ dissolution of all previously adsorbed or precipitated metals were predicted, compared to their speciation at site specific $\mathrm{pH}$. At $\mathrm{pH}$ 6, Al, Cd, Fe and $\mathrm{Zn}$ increased their dissolution. $\mathrm{Zn}$ was predicted to dissolve most in all model runs, on average with $50 \%$ more dissolution than site 25 specific $\mathrm{pH}$, but up to $80 \%$ more dissolution in $\mathrm{T} 6 \mathrm{a}$ (from $\mathrm{pH} 8.5$ to $\mathrm{pH} 6$ ). Dissolution of ferrihydrite on average increased by $16 \%$, which was more than for $\mathrm{Al}(5 \%)$ and $\mathrm{Cd}$ $(6 \%)$. However, for $\mathrm{As}, \mathrm{V}$ and $\mathrm{Pb}$ their dissolved fraction instead decreased by changing the $\mathrm{pH}$ to 6 , on average by $11 \%(\mathrm{As})$ and $19 \%(\mathrm{~Pb}, \mathrm{~V})$, due to increased sorption to ferrihydrite.

$$
9729
$$

Increasing the DOC concentration by $50 \%$ from measured values in 2012 resulted in predicted increased overall dissolution of all investigated metals, with greatest impact on $\mathrm{Fe}, \mathrm{Pb}$ and $\mathrm{Zn}$ solubility; up to $10 \%$. This increase in DOC concentrations correspondingly lead to predicted increased Fe-organic complexation, with a few percent.

\section{Discussion}

The main chemical parameter controlling solubility of metals in aqueous systems is often considered to be $\mathrm{pH}$ (e.g. Bourg and Loch, 1995). Agreement between the present observations of high concentrations of metals in suspension and predicted precipitation and/or sorption controls, show that dissolution is generally limited for several

10 metals under the alkaline conditions that prevail at Zaamar Goldfield. Through the scenario modelling where $\mathrm{pH}$ was altered from actual site conditions, it becomes apparent that there is a strong $\mathrm{pH}$ dependence of several metals in this system. The scenario modelling at $\mathrm{pH} 3.5$ represents $\mathrm{pH}$ conditions common at many well studied acid mine drainage sites (e.g. Elliot et al., 1998; Saria et al., 2006). Under such conditions, practi-

5 cally all metals are dissolved. Model predictions at the $\mathrm{pH} 6$ scenario compared to site conditions also changed the speciation of the metals, however with higher sensitivity for some ( $\mathrm{Zn}, \mathrm{V}, \mathrm{Pb}$ and $\mathrm{Fe})$ than for others (Al, As, Cd). The substantial dissolution of $\mathrm{Zn}$ between site conditions and $\mathrm{pH} 6$ suggest that it is very sensitive to fluctuations in $\mathrm{pH}$. This agrees with results from for instance Chen et al. (1997), who also showed

$20 \mathrm{Zn}$ to be $\mathrm{pH}$ sensitive, with a significantly decreasing solubility above $\mathrm{pH} 6.5$, where all dissolved $\mathrm{Zn}$ was removed from solution due to adsorption.

Adsorption is a main process responsible for limiting dissolved forms of metals in natural systems (e.g. Zhao et al., 2011). A high affinity of "divalent base metals", including $\mathrm{Cd}, \mathrm{Cu}, \mathrm{Pb}$ and $\mathrm{Zn}$, to adsorb to solid phases, such as $\mathrm{Al}$ and Fe-hydroxides is

25 common (e.g. Early, 1999). In the here modeled system, adsorption to Al (gibbsite) was predicted to limit $\mathrm{Cd}$ and $\mathrm{Zn}$ solubility, with highest impact on $\mathrm{Zn}$ and minor influence on $\mathrm{Cd}$. Further, as $\mathrm{Pb}$ was predicted to adsorb to gibbsite instead of ferrihydrite where $\mathrm{Al}$ 
concentrations reached double Fe concentrations this solid could also control $\mathrm{Pb}$ solubility. Studies on the adsorption to gibbsite under high $\mathrm{pH}$ conditions are not abundant, however Weerasooriya et al. (2001) showed sorption of $\mathrm{Pb}$ to gibbsite, in the same range as predicted here, with up to $50 \%$ sorption to gibbsite at $\mathrm{pH} 9$, supporting our 5 results. Otherwise, sorption of metals to ferrihydrite is commonly reported (e.g. Shultz et al., 1987; Jung et al., 2005; Sanchez-España et al., 2006) and was here predicted to be the main solid for adsorption of $\mathrm{As}, \mathrm{Pb}$ and $\mathrm{V}$. The degree of sorption of these metals were all predicted to increase as the input $\mathrm{pH}$ was changed to 6 , suggesting these metals to be more soluble at the non-acidic site conditions than at $\mathrm{pH} 6$. How-

10 ever, results from the predictions at $\mathrm{pH} 3.5$, showing complete dissolution of previously sorbed metals, indicate that sorption is not an active control under acidic mine drainage conditions. Several other studies have shown highest adsorption of these metals to ferrihydrite at circum-neutral pH. For example, Sanchez-España et al. (2006), showed 90-99\% adsorption of $\mathrm{As}$ and $\mathrm{Pb}$ to ferrihydrite within the $\mathrm{pH}$ range 7-8. Further, Jung

15 et al. (2005) indicated $95 \%$ adsorption of $\mathrm{Cd}, \mathrm{Pb}$ and $\mathrm{Zn}$ onto ferrihydrite at $\mathrm{pH} 7$. This suggest that adsorption onto ferrihydrite mainly limits dissolved forms of these metals at circum-neutral $\mathrm{pH}$, but with adsorption still occurring at the very high $\mathrm{pH}$ conditions predicted in our study; with up to $50 \%$ sorption of $\mathrm{As}, \mathrm{Pb}$ and $\mathrm{V}$ to ferrihydrite.

Although locations with high adsorption of $A s$ and $\mathrm{V}$ was predicted here, these met20 als were overall dominantly found in their dissolved inorganic fractions $\left(\mathrm{HAsO}_{4}^{2-}\right.$ and $\mathrm{HVO}_{4}^{2-}$ ), indicating higher bioavailability of these compared to the others. As is well known to be highly dissolved at alkaline conditions (e.g. Early, 1999), especially in combination with non-humid climates (Smedley and Kinniburgh, 2002), which agrees with our results. Wällstedt et al. (2010) found, using the same modeling approach as

25 this study, that both As and $\mathrm{V}$ were dominated by their dissolved fractions in streams with $\mathrm{pH}$ above 6.9. Further, since dissolved As concentrations reached above concentrations commonly found in freshwaters (Smedley and Kinniburgh, 2002) and health risk-based guideline values (WHO) in several locations, this metal is of additional toxic concern. A recent paper on As contamination in Mongolia (Pfeiffer et al., 2014) also

9731

show high As concentrations in several regions, with highest values in areas of gold mines (including Zaamar Goldfield), highlighting this problem.

Model results also suggested that dissolved organic matter (DOC) influenced the speciation of several metals. DOC mainly controlled the dissolved form of $\mathrm{Cd}$ in both 5 campaign years and $\mathrm{Pb}$ in 2013 and also impacted $\mathrm{Zn}$. Many studies (e.g. Christensen et al., 1996; Hagedorn et al., 2000; Sauvé et al., 2000) have suggested DOC to be an important controlling factor for metal transport and fate in natural systems. A modeling approach by Weng et al. (2002) showed that metal complexes with organic matter could lead to dissolved metal concentrations of up to two orders of magnitude greater than without DOC, especially at alkaline conditions. This was most pronounced for $\mathrm{Pb}$ and $\mathrm{Cu}$, whereas for $\mathrm{Cd}$ and $\mathrm{Zn}$ the effects were smaller. Antoniadis and Alloway (2002) however found that complexation with DOC significantly increased the dissolved concentrations of $\mathrm{Cd}$ and $\mathrm{Zn}$; a result that agrees with the model results from this study. Additionally, binding of Fe and Al to organic matter has been shown to affect the bind15 ing of other metals as well. High concentrations of Fe and Al were shown by Tipping et al. (2002) to dominate the space at the organic material, thus increasing the dissolved concentrations of other metals which could no longer stay in a complex with the organic material. This was seen for Fe in our modeled system; with the scenario of increased DOC concentrations by $50 \%$, Fe-organic complexation also increased. This

20 was also predicted to increased the dissolved fraction of previously adsorbed metals to ferrihydrite. If site specific DOC concentrations were higher than the here assumed values for the 2012 campaign, more metal-organic complexes could exist in our system than what was predicted, suggesting that the systematic under-prediction of the dissolved fraction for many metals in 2012 (Fig. 4a) could be related to DOC. Several 25 studies (e.g. Schelker et al., 2012; Raymond and Saiers, 2010) have showed DOC fluctuations with up to several $100 \%$, for instance due to land use changes (deforestation) and storm events. Since data on DOC variability in the studied region is scarce (Yoshioka et al., 2002), it is possible that real DOC concentrations in 2012 were much higher than in 2013. 
As mentioned in the result Sect. 4.3 model and measured results on the speciation of $\mathrm{Cr}, \mathrm{Cu}, \mathrm{Mn}$ and Mo did not agree. A possible reason to this is the impact of adsorption to precipitates not included in the model. Apatites, a group of phosphate minerals, have commonly been suggested to be main solids limiting the dissolved form of sev-

5 eral metals in natural systems (e.g. Chen et al., 1997). Notably, Hydroxyapatite, which is a natural calcium phosphate mineral within the apatite group, could be an important solid providing adsorption sites, since it was oversaturated (i.e. would precipitate if added as a possible solid phase) according to the model throughout the modeled river reach. Measured concentrations of particulate calcium and phosphorous, which

10 are chemical constituents of the mineral, were also considerable in the Tuul River, suggesting that the mineral can be present in the system. However it would be premature to add this mineral to the model as a possible solid for adsorption, due to the current lack of an adsorption database for this phase. Nevertheless, several previous studies (e.g. Corami et al., 2008, 2012; Chen et al., 2010; Feng et al., 2010) have pointed to the 15 importance of this solid for adsorption of metals, including $\mathrm{Cr}$, $\mathrm{Cu}$ and Mo. For example, Cr adsorption to hydroxyapatite was shown experimentally by Asgari et al. (2012) to remove high fractions of dissolved $\mathrm{Cr}$, up to $\mathrm{pH} 11$. Hence, Hydroxyapatite could be an active control of several metals in non-acidic systems, even if its sorption database is currently lacking.

$20 \quad$ Linking the results from the speciation modelling with the measured concentrations and mass flow quantifications highlights the strong correlation between the predicted forms of precipitated $\mathrm{Fe}$ and $\mathrm{Al}$ and their high impact of suspended to total transport. The potential capacity of sediments to hold much more metals than corresponding volume of water is well known (e.g. Horowitz, 1991) and the combined effects of the mining activities; stirring up metal rich bottom sediments, and the non-acidic environment; precipitating $\mathrm{Al}$ and $\mathrm{Fe}$ and enhancing adsorption of several other metals, leads to overall high export of several metals in suspension from the site. This is in line with previous site assessments (Thorslund et al., 2012), suggesting a net contribution of metal loads transported from Zaamar Goldfield compared to natural mass flows. Since

$$
9733
$$

concentrations of metals did not vary as much as discharges, discharge would be the main factor controlling the magnitude of mass flows. This impact of discharge on pollutant loads was also seen by Basu et al. (2010).

Considering combined influences of land use alterations (expansion of mining areas) 5 and projected climate change (increasing the frequency of peak flow events; Altansukh and Davaa, 2011), which likely result in increased discharge and erosion in the Lake Baikal Drainage Basin, one can expect that the transport of metals from the site to the connected river system will also increase. The transport of metals to downstream regions, where geochemical conditions might be different (e.g. Yoshioka et al., 2002),

10 could potentially increase the solubility and bioavailability of metals in suspension. This highlights the need for further studies focusing on large-scale implications of coupled hydrodynamic (governing the magnitude of suspended sediment transport) and geochemical (governing the mobility of metals between the sediment and water phase) processes.

\section{Conclusions}

Under non-acidic conditions, riverine suspended mass flows typically constitutes a dominating part of total mass flows, such as observed during our snapshot measurements in the Tuul river at Zaamar Goldfield. Total mass flows showed net increases over the mining site, reflecting export of several metals (Al, Cd, Fe, Mn, Pb and V) from the site to the downstream river system. Our results show that $\mathrm{Zn}$ partitioning had a particularly high sensitivity to $\mathrm{pH}$ under circum-neutral and high-pH conditions $\mathrm{pH} 6$ to 9.6), which contrasts to near $100 \% \mathrm{Zn}$ dissolution under different conceivable acid mine drainage conditions (below pH 6). At site specific $\mathrm{pH}(8-9.6)$, between 50-80\% of the available $\mathrm{Zn}$ was sorbed onto gibbsite.

Another main difference from acid mine drainage geochemistry is that the prevailing high $\mathrm{pH}$ causes precipitation of ferrihydrite and gibbsite, which removes between 90 to $100 \%$ of Fe and $\mathrm{Al}$ from solution. This notably influences the behavior of $\mathrm{As}, \mathrm{Pb}$ and $\mathrm{V}$ 
since their solubilities are controlled by sorption onto ferrihydrite. For instance, $40 \%$ of available $\mathrm{Pb}, 40 \%$ of available $\mathrm{V}$ and $10 \%$ of available As was sorbed to ferrihydrite at $\mathrm{pH}$ above 8. Despite high $\mathrm{pH}$ conditions, As and $\mathrm{V}$ predominantly occurred in dissolved inorganic forms $\left(\mathrm{HAsO}_{4}^{2-}\right.$ and $\mathrm{HVO}_{4}^{2-}$, respectively). Arsenic also showed dissolved

5 concentrations above health risk-based guideline values in several locations and can thus be of main toxic concern in the upper Lake Baikal Drainage Basin.

Model results also indicated that the speciation of $\mathrm{Cd}, \mathrm{Pb}$ and $\mathrm{Zn}$ was to large extent influenced by complexation with DOC (up to $70 \%$ bound to DOC). In high pH environments, most metals have relatively low solubility in absence of DOC. However, present

10 modelling showed that in particular the solubility $\mathrm{Fe}, \mathrm{Pb}$ and $\mathrm{Zn}$ can increase considerably as DOC concentrations increase (up to $10 \%$ higher solubility for $50 \%$ DOC concentration increase). In high $\mathrm{pH}$ systems, seasonality of DOC concentrations (which could vary by several $100 \%$ ) can therefore have a major influence on the spreading and toxicity of these metals. Furthermore, the spreading of $\mathrm{Fe}, \mathrm{Pb}$ and $\mathrm{Zn}$ can then 15 also change considerably in response to climate and land use changes that impact DOC concentrations, such as increasing frequency of storm events, agricultural expansion and deforestation.

For most metals, model results on their dissolution generally agreed well (within $20 \%$ difference in dissolved fractions) with observations in the Tuul River. However, the 20 model predicted $\mathrm{Cr}$, $\mathrm{Cu}$ and $\mathrm{Mo}$ to be $100 \%$ in solution whereas observational data showed that up to $60 \%$ of their mass could be attached to particles in suspension. A possible reason for this discrepancy is that the model neglected the influence of sorption to hydroxyapatite, an apatite mineral known to have high sorption capacity. Nevertheless, its adsorption database is currently lacking, which hinders appropriate sorption quantification. The potential importance of this mineral for metal partitioning under non-acidic conditions in general, and for the investigated Tuul River in particular, is emphasized by the fact that this mineral's constituents were observed on-site, with conditions being favorable for its precipitation.

Author contribution. J. Thorslund did model simulations and manuscript preparation, with contributions from all co-authors. J. Thorslund, J. Jarsjö and S. Chalov developed research ideas, including field preparations, measurements and modelling approach. T. Wällstedt was responsible for modelling aspects, including parameter settings. M. Mörth was responsible for analytical

5 methods, sampling handling and analysis. M. Lychagin contributed to geochemical interpretation.

Acknowledgements. This research is conducted within the project; Basin-scale hydrological spreading of pollutants and wetland opportunities for reducing them under different hydroclimatic and other regional conditions, funded by the Swedish Research Council Formas (project 10 2012-790). This study is also part of the project; Hydroclimatic and ecohydrological changes of the Lake Baikal drainage basin, financially supported by a travel grant from the Faculty of Science, Stockholm University. This work is additionally implemented under the support of Russian-Mongolian biological expedition RAS-MAS, Russian geographical society grant "Expedition Selenga-Baikal", Russian Foundation for Basic Research (project nr. 12-05-00069-a, 15 12-05-33090).

\section{References}

AATA International Inc.: Social and Environmental Impact Assessment, Big Bend Placer Gold Mining Project, Mongolia, Denver, Colorado, USA, 2008.

Alexeevsky, N. I., Chalov, R. S., Berkovich, K. M., and Chalov, S. R.: Channel changes in largest

20 Russian rivers: natural and anthropogenic effects, Int. J. River Basin Manage., 11, 175-191, doi:10.1080/15715124.2013.814660, 2013.

Altansukh, O. and Davaa, G.: Application of index analysis to evaluate the water quality of the Tuul River in Mongolia, J. Water Resour. Protect., 3, 398-414, 2011.

Antoniadis, V. and Alloway, B. J.: The role of dissolved organic carbon in the mobility of $\mathrm{Cd}, \mathrm{Ni}$ and $\mathrm{Zn}$ in sewage sludge-amended soils, Environ. Pollut., 117, 515-521, 2002.

Asgari, G., Rahmani, A. R., Faradmal, J., and Seid Mohammadi, A. M.: Kinetic and isotherm of hexavalent chromium adsorption onto nano hydroxyapatite, J. Res. Health Sci., 12, 45-53, 2012. 
Balistrieri, L. S., Seal, R. R., Piatak, N. M., and Paul, B.: Assessing the concentration, speciation, and toxicity of dissolved metals during mixing of acid-mine drainage and ambient river water downstream of the Elizabeth Copper Mine, Vermont, USA, Appl. Geochem., 22, 930-952, 2007.

5 Basu, N. B., Destouni, G., Jawitz, J. W., Thompson, S. E., Loukinova, N. V., Darracq, A., Zanardo, S., Yaeger, M., Sivapalan, M., Rinaldo, A., and Rao, P. S. C.: Nutrient loads exported from managed catchments reveal emergent biogeochemical stationarity, Geophys. Res. Lett., 37, 1-5, doi:10.1029/2010GL045168, 2010.

Bourg, A. C. M. and Loch, J. P. G.: Mobilization of metals as affected by $\mathrm{pH}$ and redox conditions, in: Biogeodynamics of Pollutants in Soils and Sediments, edited by: Salomons, P. D. W. and Stigliani, P. D. W. M., Environmental Science, Springer, Berlin, Heidelberg, 87-102, 1995.

Butler, B. A., Ranville, J. F., and Ross, P. E.: Observed and modeled seasonal trends in dissolved and particulate $\mathrm{Cu}, \mathrm{Fe}, \mathrm{Mn}$, and $\mathrm{Zn}$ in a mining-impacted stream, Water Res., 42, 3135-3145, 2008.

Bykov, V. D. and Vasil'ev, A. V.: Hydrometry, Gidrometeoizdat, Leningrad, 1972.

Caruso, B. S., Cox, T. J., Runkel, R. L., Velleux, M. L. Bencala, K. E., Nordstrom, D. K., Julien, P. Y., Butler, B. A., Alpers, C. N., Marion, A., and Smith, K. S.: Metals fate and transport modelling in streams and watersheds: state of the science and USEPA workshop review, Hydrol. Process., 22, 4011-4021, 2008.

Chalov, S. R., Zavadsky, A. S., Belozerova, E. V., Bulacheva, M. P., Jarsjö, J., Thorslund, J., and Yamkhin, J.: Suspended and dissolved matter fluxes in the upper Selenga river basin, Geogr. Environ. Sustain., 5, 78-94, 2012.

Chalov, S. R., Jarsjö, J., Kasimov, N. S., Romanchenko, A. O., Pietro, J., Thorslund, J., and Promakhova, E. V.: Spatio-temporal variation of sediment transport in the Selenga River Basin, Mongolia and Russia, Environ. Earth Sci., doi:10.1007/s12665-014-3106-z, in press, 2014.

Chen, S. B., Ma, Y. B., Chen, L., and Xian, K.: Adsorption of aqueous $\mathrm{Cd}^{2+}, \mathrm{Pb}^{2+}, \mathrm{Cu}^{2+}$ ions by nano-hydroxyapatite: single- and multi-metal competitive adsorption study, Geochem. J., 44, 233-239, 2010.

Christensen, J. B., Jensen, D. L., and Christensen, T. H.: Effect of dissolved organic carbon on the mobility of cadmium, nickel and zinc in leachate polluted groundwater, Water Res., 30, 3037-3049, 1996.

9737

Cidu, R., Biddau, R., and Fanfani, L.: Impact of past mining activity on the quality of groundwater in SW Sardinia (Italy), J. Geochem. Explor., 100, 125-132, 2009.

Corami, A., Mignardi, S., and Ferrini, V.: Cadmium removal from single- and multi-metal (Cd plus $\mathrm{Pb}$ plus $\mathrm{Zn}$ plus $\mathrm{Cu}$ ) solutions by sorption on hydroxyapatite, J. Colloid Interf. Sci., 317, 402-408, 2008.

Dennis, I. D.: The impact of historical metal mining on the river Swale catchment, North Yorkshire, UK Unpublished Ph.d. Thesis, Institute of Geography and Earth Sciences, University of Wales, Aberystwyth, 2005.

Destouni, G., Persson, K., Prieto, C., and Jarsjö, J.: General quantification of catchment-scale

10 nutrient and pollutant transport through the subsurface to surface and coastal waters, Environ. Sci. Technol., 44, 2048-2055, 2010.

Dzombak, D. A. and Morel, F. M. M.: Surface Complexation Modeling: Hydrous Ferric Oxide, 1st Edn., Wiley-Interscience, 1990.

Eary, L. E.: Geochemical and equilibrium trends in mine pit lakes, Appl. Geochem., 14, 963987, 1999

Elliot, P., Ragusa, S., and Catcheside, D.: Growth of sulfate-reducing bacteria under acidic conditions in an upflow anaerobic bioreactor as a treatment system for acid mine drainage, Water. Res., 32, 3724-3730, 1998.

Feng, Y., Gong, J. L., Zeng, G. M., Niu, Y. Q., Zhang, H. Y., Niu, Q. Y., Deng, J. H., and Yan, M.: Adsorption of Cd (II) and Zn (II) from aqueous solutions using magnetic hydroxyapatite nanoparticles as adsorbents, Chem. Eng. J., 162, 487-494, 2010.

Foster, I. D. L. and Charlesworth, S. M.: Heavy metals in the hydrological cycle: trends and explanation, Hydrol. Process., 10, 227-261, 1996.

Fytianos, K.: Speciation analysis of metals in natural waters: a review, J. AOAC Int., 84, 17631769, 2001.

GEMStat: Global Water Quality Database, available at: http://www.gemstat.org (last access: 22 October 2013), 2011.

Grosbois, C., Schaefer, J., Bril, H., Blanc, G., and Bossy, A.: Deconvolution of trace element (As, $\mathrm{Cr}$, Mo, Th, U) sources and pathways to surface waters of a gold mining-influenced watershed, Sci. Total Environ., 407, 2063-2076, 2009.

Gundersen, P. and Steinnes, E.: Influence of temporal variations in river discharge, pH, alkalinity and $\mathrm{Ca}$ on the speciation and concentration of metals in some mining polluted rivers, Aquat. Geochem., 7, 173-193, 2001. 
Gustafsson, J. P.: Visual MINTEQ, Version 3.0: a Window Version of MINTEQA2, Version 4.0, available at: http://www.Iwr.kth.se/english/OurSoftware/Vminteq (last access: 8 August 2014), 2010.

Gustafsson, J. P., Dässman, E., and Bäckström, M.: Towards a consistent geochemical model

5 for prediction of uranium( $\mathrm{VI})$ removal from groundwater by ferrihydrite, Appl. Geochem., 24, 454-462, 2009.

Gustafsson, J. P., Persson, I., Oromieh, A. G., van Schaik, J. W. J., Sjöstedt, C., and Kleja, D. B.: Chromium(III) complexation to natural organic matter: mechanisms and modeling, Environ. Sci. Technol., 48, 1753-1761, 2014.

10 Hagedorn, F., Kaiser, K., Feyen, H., and Schleppi, P.: Effects of redox conditions and flow processes on the mobility of dissolved organic carbon and nitrogen in a forest soil, J. Environ. Qual., 29, 288-297, 2000.

Horowitz, A. J.: A Primer on Sediment-Trace Metal Chemistry, 2nd Edn., USGS Water Supply Paper 2277, Lewis Publishers, MI, 1991.

15 Hudson-Edwards, K. A.: Sources, mineralogy, chemistry and fate of heavy metal-bearing particles in mining-affected river systems, Mineral. Mag., 67, 205-217, 2003.

Inam, E., Khantotong, S., Kim, K.-W., Tumendemberel, B., Erdenetsetseg, S., and Puntsag, T.: Geochemical distribution of trace element concentrations in the vicinity of Boroo gold mine, Selenge Province, Mongolia, Environ. Geochem. HIth., 33, 57-69, 2011.

20 Jung, H. B., Yun, S. T., Mayer, B., Kim, S. O., Park, S. S., and Lee, P. K.: Transport and sediment-water partitioning of trace metals in acid mine drainage: an example from the abandoned Kwangyang A-Ag mine area, South Korea, Environ. Geol., 48, 437-449, 2005.

Karamalidis, A. K. and Dzombak, D. A.: Surface Complexation Modeling: Gibbsite, John Wiley \& Sons, Weinheim, Germany, 294 pp., 2010.

25 Khai, N. M., Öborn, I., Hillier, S., and Gustafsson, J. P.: Modeling of metal binding in tropical Fluvisols and Acrisols treated with biosolids and wastewater, Chemosphere, 70, 1338-1346, 2008.

Khazheeva, Z. I., Tulokhonov, A. K., and Urbazaeva, S. D.: Distribution of metals in water, bottom silt, and on suspensions in the arms of the Selenga delta, Chem. Sustain. Dev., 14, 279-285, 2006.

Korfali, S. I. and Davies, B. E.: Speciation of metals in sediment and water in a river underlain by limestone: role of carbonate species for purification capacity of rivers, Adv. Environ. Res., 8, 599-612, 2004.

9739

Landner, L.: Speciation, mobility and bioavailability of metals in the environment, in: Metals in Society and in the Environment, Environmental Pollution, Springer, the Netherlands, 139274, 2005.

Lee, Y. J., Yun, S. T., Badarch, M., Lee, J., Ayur, O., Kwon, J. S., and Kim, D. M.: Joint Research between Korea and Mongolia on Water Quality and Contamination of Transboundary Watershed in Northern Mongolia, Korea Environmental Institute, Mongolian Nature and Environment Consortium, Seoul, Republic of Korea, 2006.

Lewin, J. and Macklin, M. G.: Metal mining and floodplain sedimentation in Britain, Int. Geomorphol., 1986, 1009-1027, 1986.

10 Lund, T. J., Koretsky, C. M., Landry, C. J., Schaller, M. S., and Das, S.: Surface complexation modeling of $\mathrm{Cu}(\mathrm{II})$ adsorption on mixtures of hydrous ferric oxide and kaolinite, Geochem. T., 9, 1-6, 2008.

Lychagin, M. Y., Tkachenko, A. N., Kasimov, N. S., and Kroonenberg, S. B.: Heavy metals in the water, plants, and bottom sediments of the Volga River mouth area, J. Coastal Res., doi:10.2112/JCOASTRES-D-12-00194.1, in press, 2013.

Macklin, M. G., Brewer, P. A., Hudson-Edwards, K. A., Bird, G., Coulthard, T. J., Dennis, I. A., Lechler, P. J., Miller, J. R., and Turner, A.: Geomorphological approach to the management of rivers contaminated by metal mining, Geomorphology, 79, 423-447, 2006.

Malmström, M. E., Berglund, S., and Jarsjö, J.: Combined effects of spatially variable flow and mineralogy on the attenuation of acid mine drainage in groundwater, Appl. Geochem., 23, 1419-1436, 2008.

MCA: Midterm Report, Annex 4, Water Quality, Chap. 5.3, available at: www.mca.mn/ document/tender/2010_060_pu_d.pdf (last access: 8 August 2014), 2011.

Mighanetara, K., Braungardt, C. B., Rieuwerts, J. S., and Azizi, F.: Contaminant fluxes from

25 point and diffuse sources from abandoned mines in the River Tamar catchment, UK, J. Geochem. Explor., 100, 116-124, 2009.

Moldovan, B. J. and Hendry, J. M.: Characterizing and quantifying controls on arsenic solubility over a pH range of 1-11 in a uranium mill-scale experiment, Environ. Sci. Technol., 39, 4913-4920, 2005.

30 Nystrand, M. I., Österholm, P., Nyberg, M. E., and Gustafsson, J. P.: Metal speciation in rivers affected by enhanced soil erosion and acidity, Appl. Geochem., 27, 906-916, 2012. 
Palleiro, L., Rodríguez-Blanco, M. L., Taboada-Castro, M. M., and Taboada-Castro, M. T.: The influence of discharge, $\mathrm{pH}$, dissolved organic carbon, and suspended solids on the variability of concentration and partitioning of metals in a rural catchment, Water Air Soil Poll., 224, 111, 2013.

5 Parkhurst, D. L. and Appelo, C. A. J.: User's Guide to PHREEQC (Version 2)3195-2011, R Program for Speciation, Batch Reaction, One-Dimensional Transport, and Inverse Geochemical Calculations, US Geological Survey Water-Resources Investigations Report 994259, US Geological Survey, Earth Science Information Center, Open-File Reports Section, 312 pp., 1999.

10 Persson, K., Jarsjö, J., and Destouni, G.: Diffuse hydrological mass transport through catchments: scenario analysis of coupled physical and biogeochemical uncertainty effects, Hydrol. Earth Syst. Sci., 15, 3195-3206, doi:10.5194/hess-15-3195-2011, 2011.

Pfeiffer, M., Batbayar, G., Hofmann, J., Siegfried, K., Karthe, D., and Hahn-Tomer, S.: Investigating arsenic (As) occurrence and sources in ground, surface, waste and drinking water in northern Mongolia, Environ. Earth Sci., doi:10.1007/s12665-013-3029-0, in press, 2014.

Pietron, J.: Modeling sediment transport in the downstream Tuul River, Mongolia, M.Sc. thesis, INK, Stockholm University, Stockholm, 2012.

Raguž, V., Jarsjö, J., Grolander, S., Lindborg, R., and Avila, R.: Plant uptake of elements in soil and pore water: field observations versus model assumptions, J. Environ. Manage., 126, 147-156, 2013.

Raymond, P. A. and Saiers, J. E.: Event controlled DOC export from forested watersheds, Biogeochemistry, 100, 197-209, 2010.

Rudneva, N. A., Pronin, N. M., and Rudneva, L. V.: Microelements and metals in the muscles of the Muskrat (Ondatra zibethica) from the Selenga River Delta, Russ. J. Ecol., 36, 435-437, 2005.

Sanches-España, J. S., Pamo, E. L., Pastor, E. S., Andrés, J. R., and Rubí, J. A. M.: The impact of acid mine drainage on the water quality of the Odiel River (Huelva, Spain): evolution of precipitate mineralogy and aqueous geochemistry along the Concepción-Tintillo segment, Water Air Soil Poll., 173, 121-149, 2006.

30 Saria, L., Shimaoka, T., and Miyawaki, K.: Leaching of heavy metals in acid mine drainage, Waste Manage. Res., 24, 134-140, 2006.

Sauvé, S., Hendershot, W., and Allen, H. E.: Solid-solution partitioning of metals in contaminated soils: dependence on $\mathrm{pH}$, total metal burden, and organic matter, Environ. Sci. Technol., 34, 1125-1131, 2000.

Schelker, J., Eklöf, K., Bishop, K., and Laudon, H.: Effects of forestry operations on dissolved organic carbon concentrations and export in boreal first-order streams, J. Geophys. Res., 117, G01011, doi:10.1029/2011JG001827, 2012.

Scultz, M. F., Benjamin, M. M., and Ferguson, J.: Adsorption and desorption of metals on ferrihydrite: reversibility of the reaction and sorption properties of the regenerated solid, Environ. Sci. Technol., 21, 863-869, 1987.

10 Sjöblom, Å., Håkansson, K., and Allard, B.: River water metal speciation in a mining region - the influence of wetlands, liming, tributaries, and groundwater, Water Air Soil Poll., 152, 173-194, 2004.

Sjöstedt, C., Wällstedt, T., Gustafsson, J. P., and Borg, H.: Speciation of aluminium, arsenic and molybdenum in excessively limed lake, Sci. Total Environ., 407, 5119-5127, 2009.

15 Sjöstedt, C., Gustafsson, J. P., and Köhler, S. J.: Chemical equilibrium modeling of organic acids, $\mathrm{pH}$, aluminum, and iron in Swedish surface waters, Environ. Sci. Technol., 44, 85878593, 2010.

Smedley, P. L. and Kinniburgh, D. G.: A review of the source, behaviour and distribution of arsenic in natural waters, Appl. Geochem., 17, 517-568, 2002.

20 Smith, K. S.: Metal sorption on mineral surfaces: an overview with examples relating to mineral deposits, in: Reviews in Economic Geology, chap. 7, The Environmental Geochemistry of Mineral Deposits, Society of Economic Geologists, Inc. (SEG), 1999.

Streat, M., Hellgardt, K., and Newton, N. L. R.: Hydrous ferric oxide as an adsorbent in water treatment: Part 2. Adsorption studies, Proc. Saf. Environ., 86, 11-20, 2008.

25 Stumm, W. and Morgan, J. J.: Aquatic Chemistry, John Wiley \& Sons, New York, 1996.

Tack, F. M. G. and Verloo, M. G.: Chemical speciation and fractionation in soil and sediment heavy metal analysis: a review, Int. J. Environ. An. Ch., 59, 225-238, 1995.

Tarras-Wahlberg, N. H., Flachier, A., Fredriksson, G., Lane, S., Lundberg, B., and Sangfors, O.: Environmental management of small-scale and artisanal mining: the Portovelo-Zaruma goldmining area, southern Ecuador, J. Environ. Manage., 65, 165-179, 2000.

Tessier, A. and Campbell, P. G. C.: Partitioning of trace metals in sediments: relationships with bioavailability, Hydrobiologia, 149, 43-52, 1987. 
Thorslund, J., Jarsjö, J., Chalov, S. R., and Belozerova, E. V.: Gold mining impact on riverine heavy metal transport in a sparsely monitored region: the upper Lake Baikal Basin case, J. Environ. Monitor., 14, 2780-2792, 2012.

Tiberg, C., Sjöstedt, C., Persson, I., and Gustafsson, J. P.: Phosphate effects on copper(II) and lead(II) sorption to Ferrihydrite, Geochim. Cosmochim. Acta, 120, 140-157, 2013.

Tipping, E.: WHAMC - a chemical equilibrium model and computer code for waters, sediments, and soils incorporating a discrete site/electrostatic model of ion-binding by humic substances, Comput. Geosci., 20, 973-1023, 1994.

Tipping, E., Lofts, S., and Lawlor, A.: Modeling the chemical speciation of trace metals in the surface waters of the Humber system, Sci. Total Environ., 210, 63-77, 1998.

Törnqvist, R., Jarsjö, J., and Karimov, B.: Health risks from large-scale water pollution: trends in Central Asia, Environ. Int., 37, 435-442, 2011.

USGS: Lake Baikal's Selenga River Delta: Biodiversity, Conservation and Sustainable Development, Institute of General and Experimental Biology, Siberian Branch, Russian Academy of

15 Sciences, Ulan-Ude, Russia, available at: http://deltas.usgs.gov/rivers.aspx?river=selenga (last access: 22 October 2013), 2011.

van Geen, A., Adkins, J. F., Boyle, E. A., Nelson, C. H., and Palanques, A.: A 120-yr record of widespread contamination from mining of the Iberian pyrite belt, Geology, 25, 291-294, 1997.

20 Wällstedt, T., Björkvald, L., and Gustafsson, J. P.: Increasing concentrations of arsenic and vanadium in (southern) Swedish streams, Appl. Geochem., 25, 1162-1175, 2010.

Weerasooriya, R., Aluthpatabendi, D., and Tobschall, H. J.: Charge distribution multi-site complexation (CD-MUSIC) modeling of $\mathrm{Pb}$ (II) adsorption on gibbsite, Colloid. Surf. A, 189, 131144,2001

25 Weng, L., Temminghoff, E. J. M., Lofts, S., Tipping, E., and Van Riemsdijk, W. H.: Complexation with dissolved organic matter and solubility control of metals in a sandy soil, Environ. Sci. Technol., 36, 4804-4810, 2002.

WHO: Guidelines for Drinking Water Quality, vol. 1, 3rd Edn., World Health Organization, Geneva, 2006.

30 Yoshioka, T., Ueda, S., Khodzher, T., Bashenkhaeva, N., Korovyakova, I., Sorokovikova, L., and Gorbunova, L.: Distribution of dissolved organic carbon in Lake Baikal and its watershed, Limnology, 3, 159-168, 2002.

9743

Zandaryaa, S., Aureli, A., Merla, A., and Janchivdorj, L.: Transboundary water pollution in Baikal Lake Basin: the role of surface-ground water interactions and groundwater, in: International Conference "Uncertainties in Water Resource Management: Causes, Technologies and Consequences", edited by: Basandorj, D. and Oyunbaatar, D., IHP Technical Documents in Hydrology 1, IHP Technical Documents in Hydrology No. 1, UNESCO Office, Jakarta, 94-105, 2008.

Zhao, G., Wu, X., Tan, X., and Wang, X.: Sorption of heavy metal ions from aqueous solutions: a review, Open Colloid Sci. J., 4, 19-31, 2011. 
Table 1. Sampling information (locations, names and dates) for water samples collected in and around the Zaamar mining areas during 2012 and 2013.

\begin{tabular}{lllll}
\hline Sample & Date & Location & $\begin{array}{r}\text { Longitude } \\
\text { (decimal degrees) }\end{array}$ \\
\hline T5 & $\begin{array}{l}\text { 24 Jun 2012 } \\
\text { 14 Sep 2013 }\end{array}$ & Tuul River, upstream of Zaamar site & 104.523 & 48.014 \\
T5a & $\begin{array}{l}\text { 24 Jun 2012 } \\
\text { 14 Sep 2013 }\end{array}$ & Tuul River, start of Zaamar site & 104.306 & 48.158 \\
T5b & $\begin{array}{l}\text { 23 Jun 2012 } \\
\text { 12 Sep 2013 }\end{array}$ & Tuul River, at Zaamar site & 104.325 & 48.229 \\
T6 & $\begin{array}{l}\text { 23 Jun 2012 } \\
\text { 11 Sep 2013 }\end{array}$ & Tuul River, at Zaamar site & 104.420 & 48.332 \\
T6a & 23 Jun 2012 & Tuul River, downstream of Zaamar site & 104.512 & 48.389 \\
& 11 Sep 2013 & & & \\
\hline
\end{tabular}

9745

Table 2. Chosen oxidation states of the various components for the input file in Visual Minteq. Since samples were collected from river water, well oxygenated conditions were assumed and thus oxidized forms of the elements were chosen. Some elements ( $\mathrm{Al}, \mathrm{Ca}, \mathrm{K}, \mathrm{Mg}, \mathrm{Na}, \mathrm{Ni}, \mathrm{P}, \mathrm{Pb}$, $\mathrm{Si}, \mathrm{Zn}$ ) only had one state in the program and could thus not be altered.

\begin{tabular}{l}
$\mathrm{Al}^{3+}, \mathrm{As}(\mathrm{V}), \mathrm{Ca}^{2+}, \mathrm{Cd}^{2+}, \mathrm{Co}^{2+}, \mathrm{Cr}(\mathrm{VI}), \mathrm{Cu}^{2+}, \mathrm{Fe}^{3+}, \mathrm{K}^{+}, \mathrm{Mg}^{2+}, \mathrm{Mn}^{2+}, \mathrm{Mo}(\mathrm{VI})$, \\
$\mathrm{Na}^{+}, \mathrm{Ni}^{2+}, \mathrm{P}\left(\mathrm{PO}_{4}\right), \mathrm{Pb}^{2+}, \mathrm{S}\left(\mathrm{SO}_{4}\right), \mathrm{Cl}^{-}, \mathrm{Si}\left(\mathrm{H}_{4} \mathrm{SiO}_{4}\right), \mathrm{V}(\mathrm{V}), \mathrm{Zn}^{2+}$ \\
\hline
\end{tabular}


Table 3. Reaction and reaction constants of the possible solid phases allowed to precipitate if their solubility constant $\left(\log K_{\mathrm{s}}\right)$ is exceeded (equations from Visual Minteq).

\begin{tabular}{llc}
\hline Mineral & Reaction & $\log K_{\mathrm{s}}\left(25^{\circ} \mathrm{C}\right)$ \\
\hline Aluminium hydroxide (soil) & $\mathrm{Al}(\mathrm{OH})_{3}+3 \mathrm{H}^{+}=\mathrm{Al}^{3+}+3 \mathrm{H}_{2} \mathrm{O}$ & 8.29 \\
Calcite & $\mathrm{CaCO}_{3}+2 \mathrm{H}^{+}=\mathrm{Ca}^{2+}+\mathrm{CO}_{2}(\mathrm{~g})+\mathrm{H}_{2} \mathrm{O}$ & -8.48 \\
Ferrihydrite (aged) & $\mathrm{Fe}(\mathrm{OH})_{3}+3 \mathrm{H}^{+}=\mathrm{Fe}^{3+}+3 \mathrm{H}_{2} \mathrm{O}$ & 2.69 \\
Gibbsite (C) & $\mathrm{Al}(\mathrm{OH})_{3}+3 \mathrm{H}^{+}=\mathrm{Al}^{3+}+3 \mathrm{H}_{2} \mathrm{O}$ & 7.74 \\
Manganite & $\mathrm{MnOOH}+3 \mathrm{H}^{+}=\mathrm{Mn}^{3+}+2 \mathrm{H}_{2} \mathrm{O}$ & 25.3 \\
\hline
\end{tabular}

Table 4. Measured geochemical parameters in the five water samples along the Tuul River reach (T5, T5a, T5b, T6, T6a) in 2012.

\begin{tabular}{llllll}
\hline Site/Parameter & T5 & T5a & T5b & T6 & T6a \\
& $2012 / 2013$ & $2012 / 2013$ & $2012 / 2013$ & $2012 / 2013$ & $2012 / 2013$ \\
\hline pH & $9.2 / 9.2$ & $9.6 / 7.6$ & $8.8 / 8.0$ & $8.5 / 8.8$ & $8.7 / 8.5$ \\
Temp $\left({ }^{\circ} \mathrm{C}\right)$ & $16.9 / 19.5$ & $19.2 / 17.0$ & $22.4 / 17.0$ & $19.1 / 17.0$ & $19.1 / 15.6$ \\
pe & $11.9 / 12.1$ & $11.0 / 13.0$ & $11.8 / 12.6$ & $12.1 / 11.8$ & $12.3 / 12.1$ \\
Alkalinity $\left(\mathrm{mg} \mathrm{L}^{-1}\right)$ & $125 / 520$ & $100 / 520$ & $98.0 / 310$ & $93.1^{\mathrm{b}} / 310$ & $80.0^{\mathrm{b}} / 310$ \\
DOC $\left(\mathrm{mg} \mathrm{L}^{-1}\right)^{\mathrm{b}}$ & $13.4 / 11.7$ & $5.77 / 11.2$ & $7.20 / 10.7$ & $6.43 / 11.5$ & $4.73 / 11.7$ \\
\hline
\end{tabular}

${ }^{a}$ calculated according to Eq. (4), ${ }^{\text {b }}$ reported data from Lee et al. (2006) 
Table A1. Detection limits (DL) for each metal from the inductive coupled plasma optical emission spectrometry (ICP-OES) analysis.

\begin{tabular}{lll}
\hline Metal DL $\left(\mu \mathrm{gL}^{-1}\right)$ & 2012 & 2013 \\
\hline $\mathrm{As}$ & 9.76 & 9.76 \\
$\mathrm{Cd}$ & 0.015 & 0.015 \\
$\mathrm{Cr}$ & 0.10 & 0.04 \\
$\mathrm{Cu}$ & 0.20 & 0.01 \\
$\mathrm{Fe}$ & 0.07 & 0.07 \\
$\mathrm{Mn}$ & 0.018 & 0.018 \\
$\mathrm{Mo}$ & 2.29 & 2.29 \\
$\mathrm{~Pb}$ & 0.10 & 0.10 \\
$\mathrm{~V}$ & 0.085 & 0.085 \\
$\mathrm{Zn}$ & 0.028 & 0.028 \\
\hline
\end{tabular}

\section{9}

Table B1. Maximum permissible concentrations levels $\left(\mu \mathrm{g} \mathrm{L}^{-1}\right)$ in drinking water according to the World Health Organization (WHO, 2006) and the Mongolian State Standard (AATA, 2008).

\begin{tabular}{lccccccccccc}
\hline & $\mathrm{Al}$ & $\mathrm{As}$ & $\mathrm{Cd}$ & $\mathrm{Cr}$ & $\mathrm{Cu}$ & $\mathrm{Fe}$ & $\mathrm{Mn}$ & $\mathrm{Mo}$ & $\mathrm{Pb}$ & $\mathrm{V}$ & $\mathrm{Zn}$ \\
\hline WHO & 200 & 10 & 3.00 & 50 & 2000 & 300 & 400 & 70 & 10 & 200 & 3000 \\
Mongolian & 500 & 10 & - & - & - & 300 & 100 & - & 10 & - & 5000 \\
\hline
\end{tabular}


Table C1. Comparison of measured and modeled dissolved fractions of the selected metals in 2012.

\begin{tabular}{llcccccccccc}
\hline \multicolumn{1}{c}{$\mathrm{Al}$} & $\mathrm{As}$ & $\mathrm{Cd}$ & $\mathrm{Cr}$ & $\mathrm{Cu}$ & $\mathrm{Fe}$ & $\mathrm{Mn}$ & $\mathrm{Mo}$ & $\mathrm{Pb}$ & $\mathrm{V}$ & $\mathrm{Zn}$ \\
\hline \multicolumn{1}{l}{$\%$ Dissolved measured } & & & & & & & & \\
\hline T5 & 0.3 & 96.5 & NA & NA & 67.5 & 3.5 & 6. & 84.5 & 72.3 & 88.7 & 57.4 \\
T5a & 0.3 & 93.4 & NA & 10. & 26.1 & 2.4 & 2. & 33.5 & NA & 73.1 & 24.7 \\
T5b & 3.6 & 85.7 & 87.1 & 39.4 & NA & 3.7 & 89.1 & 88.9 & NA & 78. & 28.1 \\
T6 & 1.1 & NA & 67.5 & 21.2 & NA & 2.3 & 2.6 & 41.2 & 12.1 & 62.8 & 44.5 \\
T6a & 4. & 92.2 & 86.9 & 35.1 & NA & 2.7 & 4.5 & 80.5 & NA & 82.2 & 64.4 \\
\hline$\%$ Dissolved modelled & & & & & & & & \\
\hline T5 & 2.63 & 72.3 & NA & NA & 100 & 2.54 & 0.00 & 100 & 48.4 & 55.0 & 45.3 \\
T5a & 1.77 & 39.8 & NA & 100 & 99.8 & 0.21 & 0.00 & 100 & NA & 37.1 & 5.76 \\
T5b & 1.29 & 94.5 & 90.2 & 100 & NA & 0.82 & 0.00 & 100 & NA & 75.6 & 23.5 \\
T6 & 0.05 & NA & 53.0 & 100 & NA & 0.46 & 0.00 & 100 & 19.4 & 52.8 & 3.08 \\
T6a & 0.78 & 98.6 & 91.4 & 100 & NA & 2.03 & 0.00 & 100 & NA & 89.2 & 24.2 \\
\hline
\end{tabular}

9751

Table C2. Comparison of measured and modeled dissolved fractions of the selected metals in 2013.

\begin{tabular}{|c|c|c|c|c|c|c|c|c|c|c|c|}
\hline & Al & As & $\mathrm{Cd}$ & $\mathrm{Cr}$ & $\mathrm{Cu}$ & $\mathrm{Fe}$ & $\mathrm{Mn}$ & Mo & $\mathrm{Pb}$ & V & $\mathrm{Zn}$ \\
\hline \multicolumn{12}{|c|}{$\%$ Dissolved Measured } \\
\hline T5 & 2.49 & NA & NA & 66.8 & 55.2 & 8.8 & 10.6 & NA & 53.4 & 40.7 & 70.2 \\
\hline T5a & 2.55 & NA & 45.1 & 92.8 & 83.7 & 6.7 & 42.3 & NA & 57.2 & 64.9 & 48.3 \\
\hline T5b & 6.07 & NA & NA & 74.8 & 69.9 & 7.5 & 25.1 & 82.0 & 50.9 & 57.5 & 105 \\
\hline T6 & 0.92 & 76.4 & 76 & 102 & 62.3 & 2.2 & 15.6 & 77.4 & 40.7 & 45.0 & 31.0 \\
\hline T6a & 11.9 & NA & NA & 75.4 & 83.6 & 3.7 & 11.7 & NA & 37.8 & 45.8 & 48.7 \\
\hline \multicolumn{12}{|c|}{$\%$ Dissolved Modelled } \\
\hline T5 & 1.54 & NA & NA & 100 & 100 & 4.27 & 0.00 & NA & 71.0 & 63.9 & 71.9 \\
\hline T5a & 0.60 & NA & 97.0 & 100 & 100 & 7.23 & 0.00 & NA & 67.0 & 56.6 & 75.0 \\
\hline T5b & 0.29 & NA & NA & 100 & 100 & 2.66 & 0.00 & 100 & 58.0 & 49.1 & 51.0 \\
\hline T6 & 0.63 & 85.0 & 91.0 & 100 & 100 & 1.21 & 0.00 & 100 & 41.1 & 53.7 & 32.0 \\
\hline T6a & 0.29 & NA & NA & 100 & 100 & 1.58 & 0.00 & NA & 45.2 & 49.7 & 21.0 \\
\hline
\end{tabular}




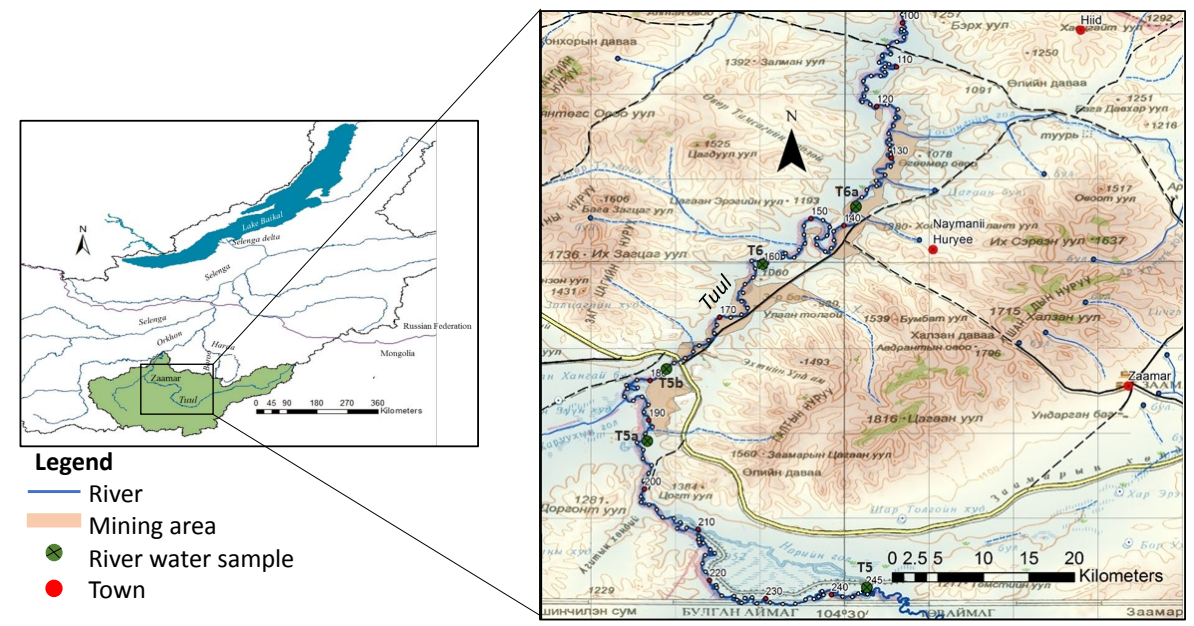

Figure 1. Map of the Baikal Basin with the Zaamar mining area (zoomed) located in the Mongolian part of the basin, along the Tuul River (author J. Thorslund).

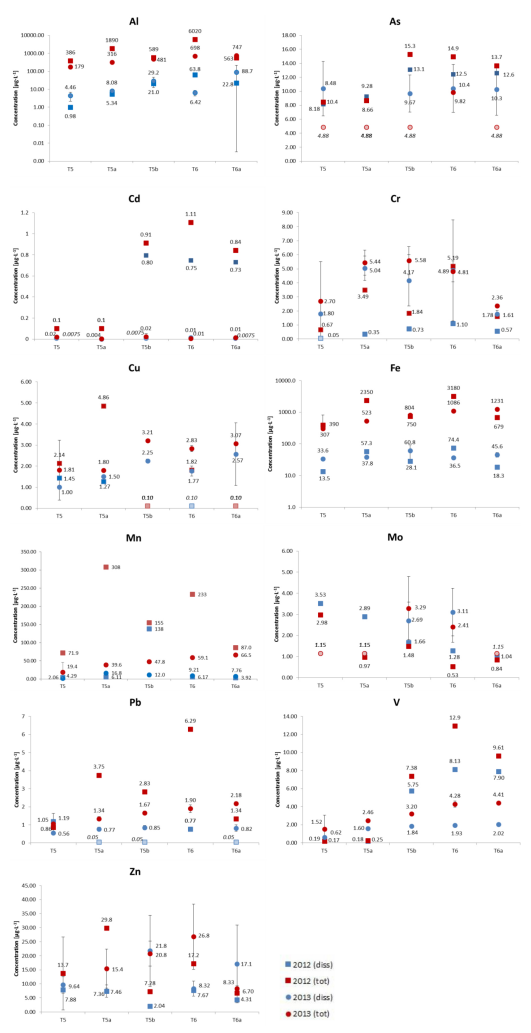

Figure 2. Dissolved (blue) and total (red) concentrations of $\mathrm{Al}, \mathrm{As}, \mathrm{Cd}, \mathrm{Cr}, \mathrm{Cu}, \mathrm{Fe}, \mathrm{Mn}, \mathrm{Mo}, \mathrm{Pb}$, $\mathrm{V}$ and $\mathrm{Zn}$ at the five sampling locations along the Tuul River and the Zaamar Goldfield, from the sampling campaigns in 2012 (squares) and 2013 (circles). 


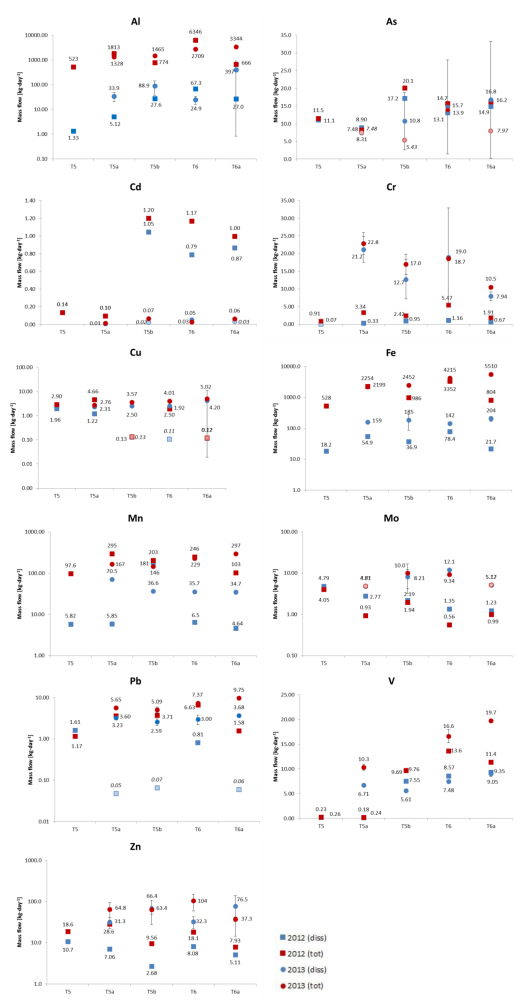

Figure 3. Estimated dissolved (blue) and total (red) mass flows, in kg per day, of Al, As, Cd, Cr, $\mathrm{Cu}, \mathrm{Fe}, \mathrm{Mn}, \mathrm{Mo}, \mathrm{Pb}, \mathrm{V}$ and $\mathrm{Zn}$ at the five sampling locations (T5-T6a) along the Tuul River and the Zaamar Goldfield, from the sampling campaigns in 2012 (squares) and 2013 (circles).

\section{5}

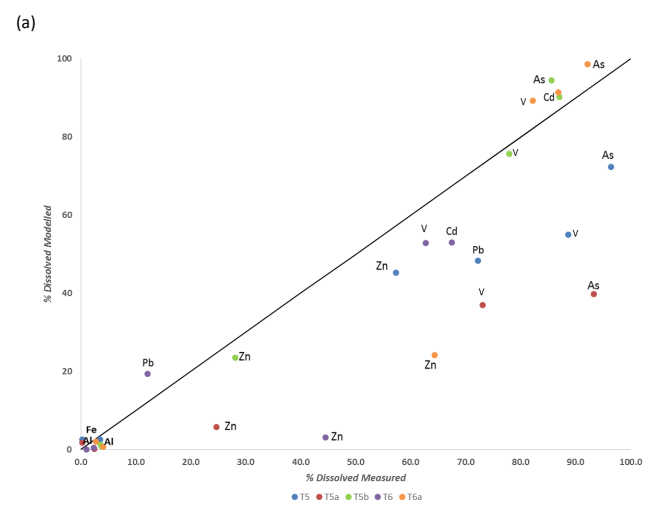

(b)

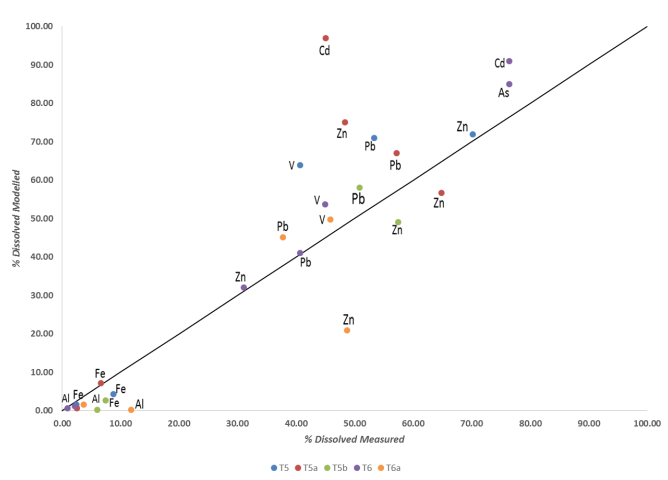

Figure 4. Comparison between measured and modeled results for the dissolved fractions (percentage) of metals in the (a) 2012 campaign and the (b) 2013 campaign. 


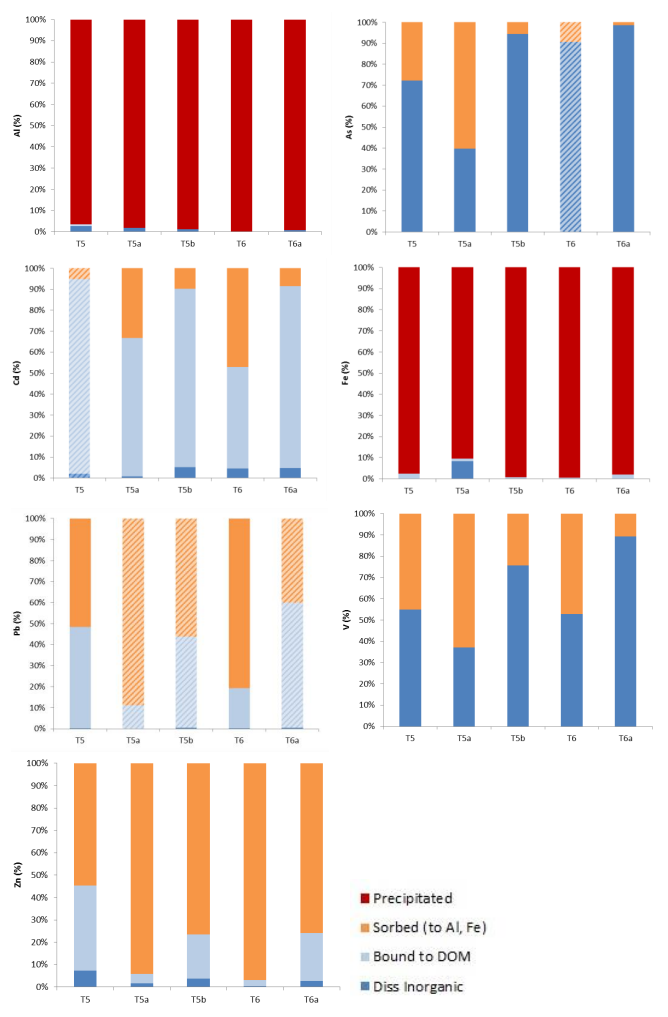

Figure 5. Predicted speciation of selected heavy metals between "dissolved inorganic", "bound to DOM", "sorbed" and "precipitated" in the five sampling locations along the Tuul River in the 2012 campaign. Dashed lines indicate model prediction from detection limit (DL) concentrations.

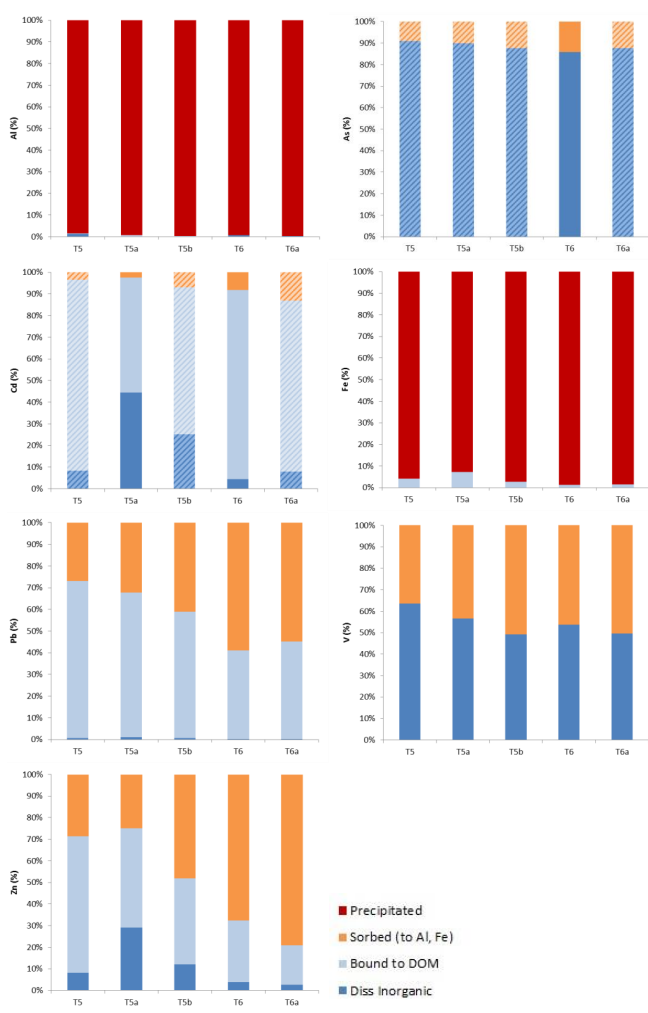

Figure 6. Predicted speciation of selected heavy metals between "dissolved inorganic", "bound to DOM", "sorbed" and "precipitated" in the five sampling locations along the Tuul River in the 2013 campaign. Dashed lines indicate model prediction from detection limit (DL) concentrations. 